Jerzy Pielaszek

\title{
SCIENTIFIC CENTER OF THE POLISH ACADEMY OF SCIENCES IN PARIS
}

(Centre Scientifique de l'Academie Polonaise des Sciences à Paris)

For both up-and-coming research grant holders from Poland and Internationallyrenowned Polish researchers, the address Rue Lauriston 74 in Paris symbolizes the very best tradition of scholarly ties between Poland and France

The Scientific Center in Paris has a history now stretching back more than 115 years - having been first established in affiliation with the Polish Library in Paris on 3 May 1893 under a decree from the President of France dated 2 July 1891. The center therefore emerged as the only independent Polish scientific unit abroad, during the very period when Poland itself lost its Independence as a country.

\section{The illustrious émigré tradition}

Polish institutions in Paris have a long tradition, dating back to the Great Emigration after 1830. One such Polish establishment is the Historical and Literary Society, which, together with the Polish Library in Paris, was granted the status of an "institution of public utility" by a decree of Napoleon III (1866). Somewhat later, the Historical and Literary Society established close ties to the Polish Academy of Arts and Sciences (PAU), which had then been set up in Kraków. In 1891 the collections of both the Historical and Literary Society and the Polish Library in Paris were taken over by the PAU, after long and difficult negotiations necessitated by the political situation in Europe. Before the official opening of the Scientific Center in Paris, the President of the PAU wrote that its main objective would be "not only to facilitate the studies of Polish scientists in Paris, but also to facilitate scholarly relations of French scientists with the Academy and with the Slavic scholarly world". After Poland regained its independence after WWI, the Scientific Center became the largest foreign scientific unit in Paris.

However, the Second World War brought great destruction and the Center was among the most heavily damaged scholarly and cultural institutions in France. The book collections, except for the most precious items that had been hidden away, were seized and taken away to Germany. After the war, a great number of these books returned 
to Paris (owing to significant help on the part of the National Library in Warsaw), and the Polish Library and the Scientific Center were then re-opened.

In 1947 the Scientific Center and the Polish Library became separate entities. Under a resolution passed by the PAU General Assembly, the Center was thenceforth meant to "serve the needs of all the divisions of the Academy" (which in those days were limited to a Philological Division and a Historical-Philosophical Division), In 1949 a portion of the building at 74 Rue Lauriston in Paris was turned over to the PAU Scientific Center, and after 1951 the entire building was taken over by the then newly-established Polish Academy of Sciences. The 74 Rue Lauriston address thus became a familiar one to nearly all Polish scientists present in Paris as well as to the French scientists collaborating with them.

Another interesting aspect of the Center is the history of its headquarters building: erected in 1908, it was originally owned by the family of Prince Clermont-Tonnerre, who were close to Marcel Proust - a fact that is marked by commemorative plaque in the hall, noting that the author of Remembrance of Things Past attended salons at the Lauriston palace. The palace was likewise frequented by the eminent Polish pianist and politician Ignacy Paderewski. Later days palace became the property of Prince Sanguszko, and in 1919 it served as headquarters for a delegation sent by Józef Piłsudski to the Versailles Conference. In the interwar years the building once again had a French owner, but it was bought back by the Poles after WWII. Nowadays it belongs to the Polish Academy of Sciences.

The political circumstances underpinning the Center's operations drastically deteriorated in the 1950s, with a certain improvement only coming after 1956. In 1957, the first agreement between the Polish Academy of Sciences and the CNRS (Centre National de la Recherche Scientifique) was signed in Warsaw, and in 1959 Poland signed a cultural and scientific cooperation agreement with France. This facilitated the gradual development of research and cultural contacts between the two countries.

\section{Contacts and collections}

Over the many years of the Center's activity, both the Polish Library building and the Rue Lauriston building have been visited by many French and Polish scholars and celebrities, hosted as guests and lecturers. Since 1970 the Center has likewise administered the buildings of the former "Polish School" at 11-15 Rue Lamandé.

The Paris Scientific Center's colorful history, replete with dramatic events, has to date been the subject of the monograph Polska Stacja w Paryż w latach 18931978 (The Polish Scientific Center in Paris in 1893-1878), published by Ossolineum 
in 1982, authored by Danuta Rederowa, Bohdan Jaczewski and Waldemar Rolbicki, with a foreword by Andrzej F. Grabski.

The first director of the Center was Prof. Stanisław Wędkiewicz, who was succeeded by the following professors: Paweł Szulkin, Witold Stefański, Feliks Widy-Wirski, Paweł Nowacki, Bolesław Kalabiński, Leszek Kasprzyk, Wiesław Skrzydło, Jerzy Borejsza, Henryk Ratajczak and (since 2004) Jerzy Pielaszek. The Scientific Center's objective, as set forth in its Statues is "to facilitate the development of scientific, $\mathrm{R} \& \mathrm{D}$, and cultural cooperation between the Republic of Poland and the Republic of France". Its activities are very diverse - it hosts and helps organize scientific conferences those inspired by programs of Polish-French (as well as European) international scientific cooperation, as well as lectures, scientific seminars, and popular-science meetings.

The Center works to foster contact between Polish and French scientific establishments and between individual scientists themselves, providing information and organizational assistance. Such efforts have given rise to successive programs of scientific cooperation. The diversity of the Center's activities is demonstrated by the variety of institutions it has cooperated with in Poland as well as in France, including the universities of Paris I, Paris II, Paris IV Sorbonne, Paris VI Pierre et Marie Curie, Paris VII, Orsay, Versailles, École Normale Supérieure de Cachan, Lille II, Rennes, Strasbourg, Toulouse, Nancy, Orléans, Marseille, Grenoble and Bordeaux. The Center likewise works together with the Polish Institute in Paris and the prestigious Literary Institute in Maisons-Laffitte in addition to the Polish Historical and Literary Society.

The Center's library collection, which began to be amassed anew in the late 1970s, now consists of around 13,000 volumes of books and 100 scientific journal titles - in Polish, French, and other languages. The library is frequented by Polish scientists in France, by grant and apprenticeship holders, and by French readers and visitors from other countries interested in Poland-related issues, including journalists preparing television or radio stories on such topics.

The Center activities are showcased in the published Annuals of the PAN Scientific Center in Paris, now entering its 11th volume (for 2008). Ongoing events and information can be found on the Center's website: www.academie-polonaise. org (e-mail: sekretariat.parispan@free.fr). 